\title{
Production of citric acid by Aspergillus niger using pineapple waste
}

\author{
Kareem, S. O.*, Akpan, I. and Alebiowu, O. O. \\ Department of Microbiology, University of Agriculture, P.M.B. 2240, Abeokuta, Nigeria. \\ E-mail: sharafkareem @yahoo.co.uk
}

Received 9 June 2009; received in revised form 22 December 2009; accepted 29 December 2009

\begin{abstract}
A solid state fermentation was developed for citric acid production from pineapple waste by Aspergillus niger KS-7. The medium was supplemented with different concentration of glucose, sucrose, ammonium nitrate and ammonium phosphate. It was found that pineapple waste with $15 \%(\mathrm{w} / \mathrm{v})$ sucrose and ammonium nitrate $(0.25 \% \mathrm{w} / \mathrm{v})$ gave the optimum citric acid secretion $(60.61 \mathrm{~g} / \mathrm{kg})$ in the presence of methanol $(2 \% \mathrm{v} / \mathrm{v})$ when fermented for 5 days at $30^{\circ} \mathrm{C}$ with the initial moisture content of $65 \%$. The yield was more than $90 \%$ based on the amount of fermentable sugar consumed. These results present the use of pineapple peel as a cheap medium for the production of commercially valuable organic acid by $A$. niger.
\end{abstract}

Keywords: Aspergillus niger, citric acid, pineapple waste, solid state fermentation

\section{INTRODUCTION}

Citric acid worldwide demand is about $6.0 \times 10^{5}$ tons per year (Karaffa and Kubicek, 2003). Approximately 75\% commercial use of citric acid is for food and $12 \%$ for pharmaceutical industries (Haq et al., 2001). Despite its wide application in food and pharmaceutical industries, citric acid is receiving little attention in the tropics.

Commercial production of citric acid is generally by submerged fermentation of sucrose or molasses using the filamentous fungus $A$. niger or synthetically from acetone or glycerol (Torres et al., 1998; Fernando et al., 2000; Adachi et al., 2003; Haq et al., 2004). In the recent times solid state fermentation (SSF) as an alternative to submerged fermentation in the production of microbial metabolites. Solid-state fermentations refer to the cultivation of microorganisms in a low-water-activity environment on a non-soluble materials acting as both nutrient source and physical support (Pandey, 2003). The major advantages of solid-state fermentation over submerged fermentation include higher yields, low water requirement and lower operating costs.

Many microorganisms have been evaluated for the production of citric acid including bacteria such as Bacillus licheniformis, B. subtilis, Corynebacterium spp. (Kapoor et al., 1983; ), fungi such as $A$. niger, $A$. awamori, $A$. foetidus, Penicillium restrictum (Mattey and Allan, 1990; Kubicek, 1998). Yeast such as Candida lipolytica, C. intermedia and Saccharomyces cerevisiae (Crolla and Kennedy, 2001; Archer et al., 2001; Kamzolova et al., 2003). However, $A$. niger a filamentous fungus remained the organism of choice for citric acid production due to ease of handling, its ability to ferment a variety of cheap raw materials, and high yields (Schuster et al., 2002). A cost reduction in citric acid production can be achieved by using cheap agricultural wastes such as apple and grape pomace, orange peel, kiwi fruit peel, cotton waste, okara soy-residue and cane molasses (Kiel et al., 1981; Hang and Woodams, 1986; 1987; Khare et al., 1995; Haq et al., 2004).

Pineapple peel is a by-product resulting from the processing of pineapple into slices and represents about $10 \% \mathrm{w} / \mathrm{w}$ of the weight of the original fruit. Current disposal of it poses considerable economic and environmental problems. The objective of this study was to adopt the use of pineapple peel as a cheap medium for the production of citric acid by $A$. niger.

\section{MATERIALS AND METHODS}

\section{Pre-treatment of pineapple peels}

Peels from pineapples bought from a local market in Abeokuta Ogun state, Nigeria were used in the present study. Pineapple peels were oven-dried at $60{ }^{\circ} \mathrm{C}$ for $2 \mathrm{~h}$ and cut into $2 \mathrm{~mm}$ mesh size.

\section{Screening of the fungal cultures}

The $A$. niger cultures were screened qualitatively for the production of citric acid as described by Ali (2004). Czapek-Dox agar medium $(10 \mathrm{~mL})$ was poured into individual sterile Petri plates and allowed to cool at room temperature. Approximately $0.5 \mathrm{~mL}$ of the conidial suspension of $A$. niger was transferred to each of the Petri plates. The plates were incubated at $30{ }^{\circ} \mathrm{C}$ for $3-5$ days. The plates were observed after incubation for yellow zones due to citric acid formation. Strains of $A$. niger with the widest yellow zone were used for further studies. 


\section{Fermentation media}

The basal medium was prepared by introducing pineapple peels $(30 \mathrm{~g})$ into $200 \mathrm{~mL}$ Erlenmeyer flasks. The medium was supplemented with glucose and sucrose at 5,10 , $15 \% \mathrm{w} / \mathrm{v}$. Effect of nitrogen supplements was studied by adding ammonium nitrate $(0.1-0.5 \%)$ and ammonium phosphate $(0.1-0.5 \%)$ to the basal medium and moistened to varying moisture content (50-70\%). The flask was cotton plugged and autoclaved at $121^{\circ} \mathrm{C}$ for 15 min. After cooling at room temperature, each medium was inoculated with the $A$. niger $\left(6.0 \times 10^{6}\right)$ suspension and incubated at different temperature range $\left(25-30{ }^{\circ} \mathrm{C}\right)$ in a rotary shaking incubator for 5 days. Methanol (0-5\%) was added to the flasks before fermentation. After fermentation, the medium was diluted with distilled water $(1: 4 \mathrm{w} / \mathrm{v})$. The medium was then filtered and the filtrate was used for the subsequent analyses.

\section{Citric acid determination}

Citric acid was determined titrimetrically (AOAC, 1995) by using $0.1 \mathrm{NaOH}$ and phenolphthalein as indicator and calculated as \% according to the formula:

$\%$ citric acid $=\frac{\begin{array}{l}\text { Normality } X \text { volume of } 0.1 \mathrm{M} \mathrm{NaOH} \times \\ \text { equivalent weight of citric acid_X dilution } \\ \text { factor }\end{array}}{\text { Weight of sample }(\mathrm{g}) \times 10}$

\section{Biomass, residual sugars and $\mathrm{pH}$ determination}

Biomass, sugar and $\mathrm{pH}$ values were determined according to AOAC (1995). To determine biomass the whole fungal culture was filtered with sterile filter paper and dried to a constant weight at $105^{\circ} \mathrm{C}$. Results were expressed in $\mathrm{g} / \mathrm{kg}$ of pineapple peel. The sugar content was determined using a refractometer and $\mathrm{pH}$ was measured by Analog $\mathrm{pH}$ meter. Each analysis was conducted in triplicate.

\section{RESULTS AND DISCUSSION}

\section{Screening of stock-cultures of $\boldsymbol{A}$. niger and pineapple medium}

Citric acid producing strains of $A$. niger isolated from various sites in Abeokuta, Nigeria were purified and their cultural and morphological characteristics were examined. Out of 35 strains screened for citric acid production, $A$. niger KS-7 was the best producer of citric acid. The pineapple peel used throughout this study was found to contain the following: crude protein $3.89 \%$; crude fat $1.57 \%$; crude fiber $2.45 \%$; carbohydrate content $42.5 \%$; sugars content $38.6 \%$; ash content $3.2 \%$ and moisture $10.25 \%$. The study shows that pineapple waste is a suitable medium for biosynthesis of citric acid by $A$. niger due to its nutritional content with optimum citric acid production at the fifth day.

\section{Effect of different concentration of sugars}

Citric acid production by $A$. niger from pineapple peels as a basal fermentation media with the different concentrations of sucrose and glucose was shown in Table 1. The medium supplemented with sucrose $(15 \%$ $\mathrm{w} / \mathrm{v})$ gave the highest citric acid value $(36.6 \mathrm{~g} / \mathrm{kg})$ while the control (pineapple peels) gave $17.23 \mathrm{~g} / \mathrm{kg}$ at 5 days fermentation period. Citric acid accumulation by $A$. niger in higher concentrations of sucrose or glucose is paralleled by a rise in the intracellular concentration of fructose 2.6 phosphate (Ali, 2004). Hossain and coworkers (1984) explained that the nature of sugar source has a marked effect on citric acid production by $A$. niger. In this study, addition of sucrose to pineapple waste enhanced citric acid production than glucose. Sucrose is the traditional commercial substrate for citric production although glucose, fructose and maltose have also been used as substrates for citric acid production (Xu et al., 1989). Sucrose is of relatively low molecular weight and is readily transported into microbial cells for hydrolysis by intracellular enzymes (Drysdale and McKay, 1995).

The increase in citric acid production and biomass values was accompanied with steady decrease in sugar along the incubation time. Kubicek (1998) reported that the final yield of citric acid in fermentation by $A$. niger is strongly dependent on the type and concentration of carbon source. Current understandings of mechanism by which the carbon source and it concentration influence citric acid accumulation were related to major regulatory points at the level of hexose transport and phosphorylation.

\section{Effect of nitrogen supplements}

Effect of nitrogen sources on citric acid productivity by $A$. niger was shown in Table 2. Supplementation of the basal medium with ammonium nitrate $(0.25 \% \mathrm{w} / \mathrm{v})$ gave an increase in citric acid production from $36.63 \mathrm{~g} / \mathrm{kg}$ to 43.10 $\mathrm{g} / \mathrm{kg}$ compared to ammonium phosphate (39.62 $\mathrm{g} / \mathrm{kg}$ ). Nitrogen had been reported to be an important factor in fermentation processes due to an increase in $\mathrm{C} / \mathrm{N}$ ratio (Pandey, 2003). Any increase or decrease other than $(0.25 \% \mathrm{w} / \mathrm{v})$ concentration, resulted in the disturbance of fungal growth and subsequently citric acid production. However, addition of ammonium nitrate $(0.5 \% \mathrm{w} / \mathrm{v})$ gave a biomass value of $13.30 \mathrm{~g} / \mathrm{kg}$ while optimum biomass $(14.40 \mathrm{~g} / \mathrm{kg})$ was obtained at $1 \% \mathrm{w} / \mathrm{v}$ concentration of ammonium phosphate. Nitrogen constituent has a profound effect on citric acid production because nitrogen is not only important for metabolic rates in the cells but it is also basic part of cell proteins. This report agreed with Grewal and Kalra (1995) that fermentation media for citric acid biosynthesis should consist of substrates necessary for the growth of microorganism primarily the carbon, nitrogen and phosphorus sources. 
Table 1: Effect of different sugar concentrations on citric acid production from pineapple waste by $A$. niger

\begin{tabular}{|c|c|c|c|c|c|c|}
\hline \multirow{2}{*}{$\begin{array}{l}\text { Fermentation } \\
\text { media }\end{array}$} & \multicolumn{6}{|c|}{$\begin{array}{c}\text { Citric acid }(\mathrm{g} / \mathrm{kg}) \text { at different incubation } \\
\text { time (days) }\end{array}$} \\
\hline & 0 & 1 & 2 & 3 & 4 & 5 \\
\hline $\begin{array}{l}\text { Pineapple } \\
\text { waste }\end{array}$ & 0 & 13.2 & 13.6 & 14.7 & 16.6 & 17.2 \\
\hline $\begin{array}{l}\text { Pineapple } \\
\text { waste }+5 \% \\
\text { glucose } \\
\text { Pineapple }\end{array}$ & 0 & 14.3 & 15.7 & 16.8 & 19.8 & 19.7 \\
\hline $\begin{array}{l}\text { Pineapple } \\
\text { waste + } \\
10 \% \text { glucose } \\
\text { Pineapple }\end{array}$ & 0 & 16.1 & 18.6 & 22.8 & 26.2 & 26.2 \\
\hline $\begin{array}{l}\text { waste + } \\
15 \% \text { glucose }\end{array}$ & 0 & 16.2 & 18.8 & 24.2 & 26.5 & 29.4 \\
\hline $\begin{array}{l}\text { Pineapple } \\
\text { waste + } 5 \% \\
\text { sucrose }\end{array}$ & 0 & 13.6 & 16.2 & 17.2 & 19.7 & 22.2 \\
\hline $\begin{array}{l}\text { Pineapple } \\
\text { waste + } \\
10 \% \text { sucrose } \\
\text { Pineapple }\end{array}$ & 0 & 17.3 & 19.1 & 21.4 & 25.8 & 29.7 \\
\hline $\begin{array}{l}\text { waste }+ \\
15 \% \text { sucrose }\end{array}$ & 0 & 21.2 & 23.3 & 26.0 & 30.4 & 36.6 \\
\hline
\end{tabular}

*Mean of triplicate determination

$\mathrm{SD} \pm 0.5$

Table 2: Effect of Nitrogen supplements on citric acid production from pineapple waste medium

\begin{tabular}{lcc}
\hline $\begin{array}{l}\text { Concentration } \\
(\% \mathrm{w} / \mathrm{v})\end{array}$ & Citric acid $(\mathrm{g} / \mathrm{kg})$ & Biomass $(\mathrm{g} / \mathrm{kg})$ \\
\hline Control & $36.63 \pm 0.5$ & $7.4 \pm 0.2$ \\
& & \\
$\mathrm{NH}_{4} \mathrm{NO}_{3}$ & $43.10 \pm 0.8$ & $10.2 \pm 0.1$ \\
0.25 & $38.20 \pm 0.5$ & $13.2 \pm 0.2$ \\
0.5 & $32.80 \pm 0.6$ & $8.2 \pm 0.1$ \\
0.75 & $26.80 \pm 0.2$ & $6.7 \pm 0.2$ \\
1.0 & & \\
& & \\
$\left(\mathrm{NH}_{4}\right)_{3} \mathrm{PO}_{4}$ & $37.10 \pm 0.5$ & $9.79 \pm 0.2$ \\
0.25 & $39.62 \pm 0.6$ & $12.7 \pm 0.2$ \\
0.5 & $31.4 \pm 0.5$ & $14.2 \pm 0.4$ \\
0.75 & $26.2 \pm 0.2$ & $14.4 \pm 0.3$ \\
1.0 & & \\
\hline
\end{tabular}

Control: Pineapple waste supplemented with sucrose (15g)

Table 3: Effect of temperature on fungal production of citric acid from pineapple peel

\begin{tabular}{cc}
\hline Temperature ${ }^{\circ} \mathrm{C}$ & Citric acid $(\mathrm{g} / \mathrm{kg})$ \\
\hline 25 & $22.5 \pm 0.5$ \\
30 & $43.5 \pm 0.5$ \\
35 & $31.6 \pm 0.6$ \\
\hline
\end{tabular}

\section{Effect of incubation temperature}

Effect of temperature on the production of citric acid was shown in Table 3 . A temperature of $30^{\circ} \mathrm{C}$ was found to be the best for citric acid production $(43.5 \mathrm{~g} / \mathrm{kg})$ in the present study. The mold produced only a small amount of citric acid at $25^{\circ} \mathrm{C}$ in five days. Sporulation however, was more marked at $35{ }^{\circ} \mathrm{C}$ than at lower temperatures. At low temperature, the low citric acid production was attributed to low enzyme activity .This report agreed with Hang and Woodams (1986) that the temperature of a fermentation medium is one of the critical factors that have a profound effect on the production of citric acid by solid state fermentation of agricultural wastes.

\section{Effect of moisture content}

Result shown in Table 4 indicated that a maximum citric acid value $(51.6 \mathrm{~g} / \mathrm{kg})$ was obtained when the initial level of moisture was $65 \%$ which was 1.5 fold increases to value obtained at $55 \%$. The importance of moisture level under SSF and its influence on the biosynthesis of microbial metabolites has been attributed to the interference of moisture in the physical properties of solid particles. Lower moisture level gives a lower degree of swelling and higher water tension, and then reduces the solubility of nutrients while higher moisture level decreases porosity, changes particle structure, promotes development of stickiness, reduces gas volume and exchange and decreases diffusion, which results in lower oxygen transfer (Lonsane et al., 1985)

\section{Effect of methanol}

Effect of methanol on citric acid production was shown in Table 5. Maximum citric acid production $(60.6 \mathrm{~g} / \mathrm{kg}$ ) was obtained at $2 \%$ concentration. An increase in citric acid production at $2 \%$ methanol concentration was in agreement with Hossain et al. (1984) who stated that the presence of methanol in fermentation media may increase citric acid production by $A$. niger. The inductive effect of methanol for citric acid production may be due to reduction of the inhibitory effects of metal ions (Kiel et al., 1981). Moyer (1953) discovered the use of low molecular weight alcohols i.e. methanol, isopropanol as adjuncts to the culture medium which greatly increased citric acid production in both surface and submerged cultures. Such uses have made it possible to ferment directly crude carbohydrate substrates.

The citric acid, residual sugar, biomass and $\mathrm{pH}$ profiles

Citric acid production and residual sugar profiles during SSF of pineapple peel by $A$. niger are presented in Figure 1. Citric acid values steadily increased with fermentation time with a maximum of $60.61 \mathrm{~g} / \mathrm{kg}$ at fifth day of fermentation. This result is quite comparable to the yields obtained by fermentation of other agricultural wastes such as kiwi fruit peel, soy-residue, and cane molasses (Hang 
Table 4: Effect of moisture level on fungal production of citric acid from pineapple peel

\begin{tabular}{cc}
\hline Moisture level $(\%)$ & Citric acid $(\mathrm{g} / \mathrm{kg})$ \\
\hline 50 & $30.20 \pm 0.8$ \\
55 & $34.20 \pm 0.8$ \\
60 & $43.51 \pm 1.1$ \\
65 & $51.11 \pm 0.5$ \\
70 & $32.41 \pm 0.5$ \\
\hline
\end{tabular}

Table 5: Effect of Methanol on citric acid production from Pineapple waste medium

\begin{tabular}{lcc}
\hline $\begin{array}{l}\text { Concentration } \\
(\% \mathrm{v} / \mathrm{v})\end{array}$ & Citric acid $(\mathrm{g} / \mathrm{kg})$ & Biomass $(\mathrm{g} / \mathrm{kg})$ \\
\hline Control & $51.1 \pm 1.0$ & $10.2 \pm 0.2$ \\
1 & $53.4 \pm 1.0$ & $10.4 \pm 0.2$ \\
2 & $60.6 \pm 1.4$ & $8.2 \pm 0.1$ \\
3 & $56.2 \pm 1.2$ & $6.4 \pm 0.1$ \\
4 & $42.1 \pm 0.8$ & $5.1 \pm 0.2$ \\
5 & $29.5 \pm 0.4$ & $4.3 \pm 0.2$ \\
\hline
\end{tabular}

Control: Pineapple waste supplemented with sucrose $(15 \mathrm{~g})$ and $\mathrm{NH}_{4} \mathrm{NO}_{3}(0.25 \% \mathrm{w} / \mathrm{v})$

and Woodams, 1985; Khare et al., 1995; Haq et al., 2004).

In the present study, a parallel relationship between citric acid production and the consumption of sugar was also observed. This result agreed with the report of El-Holi and Al-Delamy (2003) that the production of citric acid approximately paralleled the consumption of sugar. At the end of the fermentation process a significant reduction in residual sugar from $68.1 \mathrm{~g} / \mathrm{kg}$ to $4.5 \mathrm{~g} / \mathrm{kg}$ was obtained. Hang and Woodams (1986) reported that the yields of citric acid from apple and grape pomace based on the amount of sugar consumed were about $88 \%$ and $60 \%$ respectively. In this work, based on the amount of fermentable sugar consumed, the yield of citric acid was more than $90 \%$ under optimum solid-state fermentation conditions.

Biomass is a fundamental parameter in the characterization of microbial growth. The most readily measured biomass component is protein (Raimbault, 1997). A steady increase in biomass throughout the fermentation period was observed with a maximum of $10.6 \mathrm{~g} / \mathrm{kg}$ at fifth day while a decrease in $\mathrm{pH}$ from 4.0-2.5 was noted after 5 days of fermentation (Figure 2). The $\mathrm{pH}$ value maintained at the beginning of fermentation was important for a specific biomass formation. Normally, citric acid production occurred after $24 \mathrm{~h}$ of fermentation, this study shows that as incubation time increased more citric acid is produced and $\mathrm{pH}$ values decreased. Thus, the drop in $\mathrm{pH}$ observed during the process was due to the formation and accumulation of citric acid.

\section{CONCLUSIONS}

In conclusion, a solid state fermentation method has been developed for the production of citric acid from pineapple

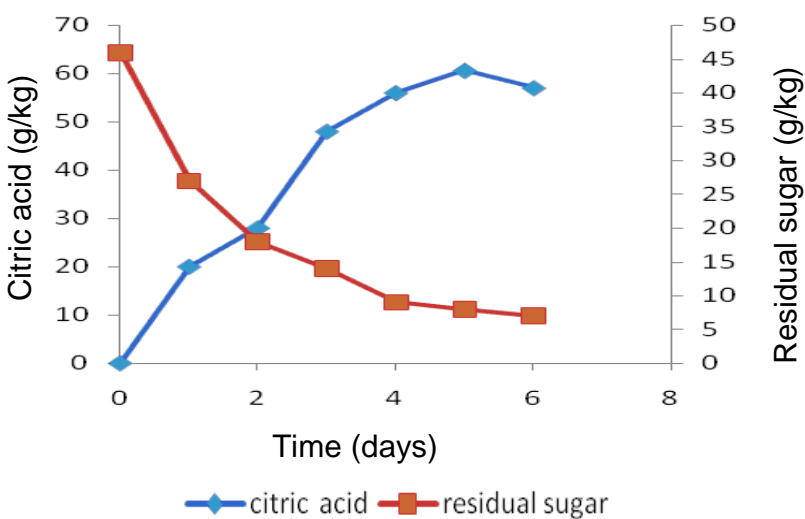

Figure 1: Time course of fungal production of citric acid from pineapple peels by $A$. niger. All the fermentations were carried out on pineapple waste supplemented with sucrose (15 g), $\mathrm{NH}_{4} \cdot \mathrm{NO}_{3}(0.25 \mathrm{w} / \mathrm{v}) \quad 2 \%$ methanol and incubated at $30^{\circ} \mathrm{C}$

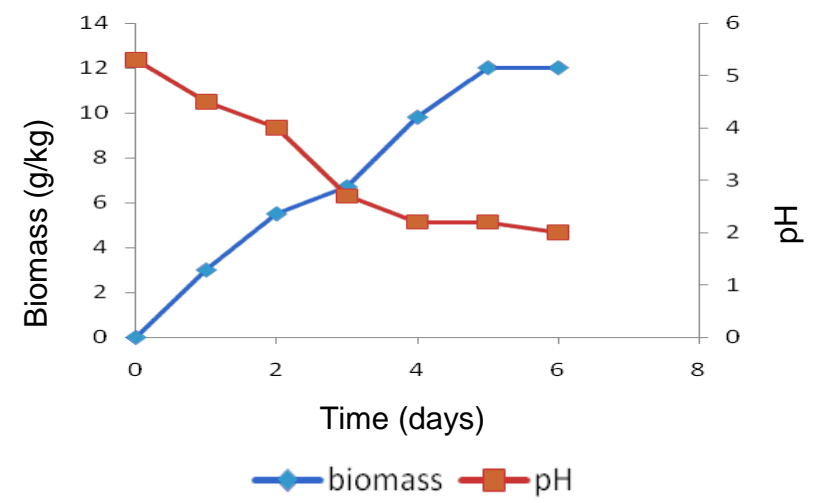

Figure 2: Biomass production and $\mathrm{pH}$ values during SSF of pineapple peels by $A$. niger. All the fermentations were carried out on pineapple waste supplemented with sucrose $(15 \mathrm{~g})$, $\mathrm{NH}_{4} \cdot \mathrm{NO}_{3} \quad(0.25 \mathrm{w} / \mathrm{v}) \quad 2 \%$ methanol and incubated at $30^{\circ} \mathrm{C}$

peel by $A$. niger. A maximum citric acid of $60.6 \mathrm{~g} / \mathrm{kg}$ of pineapple peel was obtained under optimum conditions. This study indicates that the use of pineapple peel for fungal production of citric acid might represent an efficient method of minimizing pineapple waste disposal problems and concomitantly producing organic acids of valuable importance for food and pharmaceutical industries.

\section{ACKNOWLEDGEMENT}

The authors are thankful to the Department of Microbiology, University of Agriculture, Abeokuta, Nigeria for providing necessary facilities for the present work. 


\section{REFERENCES}

Ali, S. (2004). Studies on the submerged fermentation of citric acid by Aspergillus niger in a stirred fermentor, Ph.D. Thesis. University of Punjab, Lahore, Pakistan. pp. 114-115.

AOAC (1995). Official Methods of Analysis. $16^{\text {th }}$ edn. Association of Official Analytical Chemist, Washington D.C.

Adachi, D. M., Toyama, H., Yamada, M., Shingawa, E. and Matsushita, K. (2003). New developments in oxidative fermentation. Applied Microbiology and Biotechnology 60, 643-653.

Archer, D. B., Mackenzie, A. and Jeenes, D. J. (2001). Genetic engineering; Yeasts and filamentous fungi. In: Basic Biotechnology. $2^{\text {nd }}$ edn. Ratledge, C. and Kristiansen, B. (eds.). Cambridge University Press, Cambridge pp. 95-126.

Crolla, A. and Kennedy, K. J. (2001). Optimization of citric acid production from Candida lipolytica Y-1095 using n-paraffin. Journal of Biotechnology 89, 27-40.

Drysdale, C. R. and McKay, M. H. (1995). Citric acid production by Aspergillus niger on surface culture on inolin. Letters of Applied Microbiology 20, 252-254.

El-Holi, M. A. and Al-Delamy, K. S.,(2003). Citric acid production from whey with sugars and additives by Aspergillus niger. African Journal of Biotechnology 2, 356-359.

Fernando, A. V., Carlos, G. A. and Torres, N. V. (2000). Metabolism of citric acid production by Aspergillus niger.Biotechnology and Bioengineering 70, 82-108.

Grewal, H. S. and Kalra, K. L. (1995). Fungal production of citric acid. Biotechnology Advances 13, 209-234.

Hang, Y. D. and Woodams, E. E. (1986). Utilization of grape pomace for citric acid production by Solid state fermentation. American Journal for Enology and Viticulture 37, 141-142.

Hang, Y. D. and Woodams, E. E. (1987). Microbial production of citric acid by Solid-state fermentation of Kiwi fruit peel. Journal of Food Science 52, 226-227.

Haq, I., Ali, S. and Qadeer, M. A. (2001). Fed-batch culture studies during citric acid fermentation by Aspergillus niger GCMC-7. Biologia 45, 32-37.

Hossain, M., Brooks, J. D. and Moddax, I. S. (1984). The effect of the sugar source on citric acid production by Aspergillus niger. Applied Microbiology and Biotechnology 19, 393-397.

Haq, I., Ali, S., Qadeer, M. A. and Iqbal, J. (2004). Citric acid production by mutants of Aspergillus niger from cane molasses. Bioresource Technology 93, 125130.

Kamzolova, S. V., Shishkanova, N. V., Morgunov, I. G. and Finogenova, T. V. (2003). Oxygen requirements for growth and citric acid production of Yarrowia lipolytica. Federation of European Microbiological Societies FEMS Yeast Research 3, 217-222.

Kapoor, K.K.,Chaudry, K.,Tauro,P.(1983).Citric acid. In: Prescott and Dunn's Industrial Microbiology. Reed,G.(ed.). UK: MacMillan Publishers Ltd. pp. 709747.
Karaffa, L. and Kubicek, C. P. (2003). Aspergillus niger citric acid accumulation: Do we understand this well working black box? Applied Microbiology and Biotechnology 61, 189-196.

Khare, S. K., Krishna, J. and Gandhi, A. P. (1995). Citric acid production from okara (soy-residue) by solidstate fermentation. Bioresource Technology 54, 323325.

Kiel, H., Gurin, R. and Henis, Y. (1981). Citric acid fermentation by Aspergillus niger on low sugar concentration and cotton waste. Applied Environmental Microbiology 42, 1-4.

Kubicek, C. P. (1998). The role of sugar uptake and channeling for citric acid accumulation by Aspergillus niger. Food Technology and Biotechnology 36, 173175.

Lonsane, B. K., Ghildyal, N. P., Budiatman, S., Ramakrishna, S. V. (1985). Engineering aspects of solid state fermentation. Enzyme and Microbial Technology 7, 258-265.

Mattey, M. and Allen, A. (1990). Metabolic accumulation in Aspergillus species. Biochemical society Transaction 18, 1020-265.

Moyer, A. J. (1953). Effect of alcohols on the mycological production of citric acid in surface and submerged culture. Applied Microbiology 1, 1-7.

Pandey, A. (2003). Solid-state fermentation. Biochemical Engineering Journal 13, 81-84.

Raimbault, M. (1997). General and Microbiological aspects of solid substrate fermentation. International Training Course. Solid-State fermentation. CuritibaParana, Brazil.

Schuster, E., Dunn-Coleman, N., Frisvad, J. C. and Van Dijek, P. W. (2002). On the safety of Aspergillus niger-A review. Applied Microbiology Biotechnology 59, 426-435.

Torres, N. V., Lopez, J. C., Rivero, M. G. and Rojas, M. G. (1998). Kinetics of growth of Aspergillus niger during submerged, agar surface and solid-state fermentations. Process Biochemistry 33, 103-107.

Xu, D. P., Madrid, C. P., Rohr, M. and Kubicek, C. P. (1989). The influence of type and concentration of carbon source on production of citric acid by Aspergillus niger. Applied Microbiology Biotechnology 30, 553-558. 